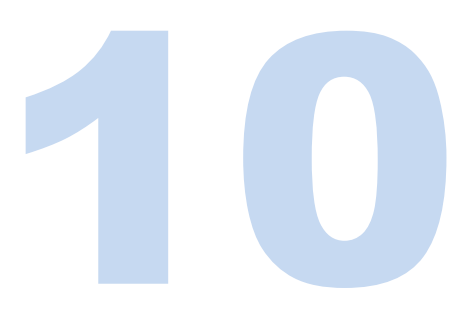

\title{
Os crimes contra a assistência familiar: as consequências do abandono afetivo paterno na vida da criança/adolescente
}

Anne Lisie de Moura Bandeira Acadêmica de Direito do Centro Universitário de Barra Mansa (UBM). ORCID: https://orcid.org/0000-0003-2565-2737

E-mail: annelisiemoura2@outlook.com

\section{Ana Maria Dinardi Barbosa Barros}

Doutouranda em Ciências Jurídicas y Sociales - Universidad del Museo Social Argentino

ORCID: https://orcid.org/0000-0001-8738-2731.

E-mail: annadinardi@hotmail.com 


\section{Resumo}

Desde o surgimento da família, deu-se início aos crimes contra a assistência familiar. Tais crimes trazem diversas consequências para aqueles que estão envolvidos, tanto ao sujeito ativo, quanto ao sujeito passivo. Dentre os crimes contra a assistência familiar, está inserido o abandono afetivo, que se trata da indiferença dos genitores quanto aos seus filhos, ou dos filhos quanto aos seus ascendentes. O presente trabalho, feito a partir de pesquisa bibliográfica, tem por objetivo demonstrar as consequências psicológicas acarretadas aos filhos, sendo trazidos desde o início do abandono até o fim da vida do filho, que por efeito do abandono, passa a moldar as suas reações ao mundo, e a vida natural de forma diversa da que poderia ser, se tivesse tido por base o afeto, o carinho e a atenção do genitor.

Palavras-Chave: Família - crimes. Abandono afetivo. Crianças e adolescentes abandono.

\section{Abstract}

Since the emergence of the family, offenses against family assistance have begun. Such effenses bring several consequences for those involved, both the active and the passive subject. Among the effenses against family assistance, there is affective abandonment, which is the indifference of parents to their children, or children to their ancestors. The present work aims to demonstrate the psychological consequences to the children, being brought from the beginning of abandonment until the end of the child's life, which by the effect of abandonment, begins to shape their reactions to the world, and the natural life of different from what it might have been if it had been based on the parent's affection, affection and attention.

Keywords: Offenses against family assistance. Affective abandonment. Consequences. 


\section{Introdução}

No presente artigo, será realizada a demonstração de forma rasa quanto ao conceito de família, entre o demonstrado por meio de dispositivos legais, como a Constituição, que é a Carta Magna, a qual todo e qualquer dispositivo legal deve estar dentre os seus limites e parâmetros.

Nesta definição prevista na Constituição quanto ao que se trata família, é possível visualizar os deveres dos pais para com seus filhos, assim como o recíproco de cuidado devido entre as partes. A partir dessa concepção, pode-se tornar o surgimento dos crimes contra a assistência familiar, que passam a existir a partir da omissão ao dever, do deixar de fazer.

Justifica-se tal artigo, pelo fato de serem perceptíveis as consequências na vida daqueles que se encontram completamente desprotegidos por parte do organismo familiar, tendo por principal objetivo a demonstração das consequências trazidas pela indiferença dos genitores em relação aos seus filhos, caracterizada pelo abandono afetivo paterno, a forma como este abandono é detectado, bem como as consequências serem apresentadas em três etapas da vida, quais sejam, a infância, a adolescência e a vida adulta.

$\mathrm{Na}$ intenção de realizar o exposto acima, foram utilizados pesquisas bibliográficas, tanto em doutrinas, quanto em estudos realizados por psicanalistas, analisando também decisões de Tribunais de Justiça, sendo realizado estudos das relações entre o abandono afetivo e as consequências trazidas por este para o sujeito passivo, bem como dos dispositivos que definem tal delito.

De forma derradeira, serão apresentadas as consequências acarretadas pelo abandono afetivo paterno na vida da criança/adolescente, que carrega tais efeitos por todo o decorrer da vida do sujeito passivo, incluindo a matéria de um documentário, o qual relata de fato, o abandono afetivo, além de estudos 
realizados por psicanalistas que buscaram através de pesquisas constatar as consequências acarretadas pelo abandono afetivo, desde a primeira infância até a fase adulta.

\section{Fundamentação Teórica}

\section{DA FAMÍLIA}

No Estado primitivo, nas sociedades primitivas, o conceito de família era algo muito restrito, no qual se conhecia tão somente o pai, ou seja, o até então, chefe de família, aquele que detinha o poder supremo, total sobre a família. Neste modelo de família, o ascendente mais velho, exercia os cargos de chefe político, sacerdote e até mesmo juiz, conforme podemos notar no estudo de Carlos Roberto Gonçalves (2012).

No entanto, esse conceito de família veio constantemente sendo alterado conforme a necessidade dessa alteração. Afinal, a família deve ser a base para a realização pessoal, o lugar de onde advém todo o aprendizado que será levado para a vida, e aquele conceito restrito onde todo o poder familiar se concentrava em só uma pessoa, já não cabe mais nos dias de hoje.

A família, segundo a Constituição da República Federativa do Brasil, representa a base da sociedade, sendo de seu dever, assim como da sociedade e do Estado, assegurar à criança, ao adolescente e ao jovem, com absoluta prioridade, o direito à vida, à saúde, à alimentação, à educação, ao lazer, à profissionalização, à cultura, à dignidade, ao respeito, à liberdade e à convivência familiar e comunitária, além de colocá-los a salvo de toda forma de negligência, discriminação, exploração, violência, crueldade e opressão. Deixando claro ainda que, os filhos havidos ou não da relação do casamento, ou por adoção, devem ter 
os mesmos direitos e qualificações, sendo proibida qualquer discriminação quanto à filiação.

Infelizmente sabemos que a realidade encontrada, se observados os fatos presentes na sociedade, é bem diferente do disposto na Constituição da República Federativa do Brasil. Desde que se ouviu falar em família, indubitavelmente, passaram a existir os crimes contra a assistência familiar. Desde as antigas famílias, nas quais os pais não aceitavam os filhos, deixando faltar o que vestir, o que comer, até o abandono total. Além disso, desde os primórdios, já podemos observar o abandono dos filhos, por exemplo, que eram concebidos fora do casamento, e em detrimento disto, eram considerados bastardos.

Consoante à existência da família, dá-se início ao crime à assistência familiar, no momento em que o responsável deixa de prover o sustento e as condições mínimas que garantam uma vida digna, ao dependente de tal apoio, seja por menor idade ou por qualquer outro motivo que lhe tornem dependentes, não só os filhos, como também os pais.

Juntamente a atualização no tangente ao conceito de família, a responsabilidade civil ganhou força, com o advento da Constituição Federal da República Federativa do Brasil, que em seu artigo $5^{\circ}$, incisos V e X, reconhece, em nível constitucional, a possibilidade da reparação pelos danos extrapatrimoniais mediante o reconhecimento através de comprovação do dano de natureza moral.

Os crimes conhecidos como crimes à assistência familiar são justamente aqueles que provém do deixar de fazer, deixar de prestar, ou seja, trata-se de crimes omissivos próprios, nos quais o sujeito ativo, deixa de cumprir com suas obrigações.

Conforme dispõe o Estatuto da Criança e do Adolescente, criança é a pessoa de até doze anos de idade incompletos, enquanto adolescente, é aquele 
entre doze e dezoito anos de idade. Tendo estes, por Lei, de forma prioritária, garantia dos direitos fundamentais, como qualquer outro ser humano, devendo ser assegurado a estes, os fins que lhes faculte o desenvolvimento físico, mental, moral, espiritual e social, em condições de liberdade e de dignidade, sem que haja qualquer tipo de discriminação.

Conforme disposto em Lei, a criança tem o direito a prioridade, sendo esta compreendida para receber proteção e socorro em quaisquer circunstâncias, precedência em atendimento nos serviços públicos, preferência até mesmo na formulação e execução de políticas públicas sociais, bem como destinação privilegiada de recursos públicos para efetividade à sua proteção.

O Código Penal elenca algumas das hipóteses de crimes contra a assistência familiar, como o abandono intelectual, o abandono moral, a entrega de filho menor à pessoa inidônea e o abandono material, no entanto, não elenca o abandono afetivo, o qual se encontra elencado na infringência do determinado nos artigos 227 e 229 da Constituição da República Federativa do Brasil, bem como no que dispõe o Estatuto da Criança e do Adolescente (Lei 8.069/1990).

Já faz parte do ordenamento jurídico brasileiro, a Lei da Primeira Infância, Lei 13.257/2016, que estabelece a forma como as políticas públicas devem ser formuladas e instituídas visando a atenção específica que a criança e o adolescente devem ter.

Neste artigo será tratado, de forma mais clara, a exposição do abandono afetivo, da forma como ele é disposto e como ocorre na nossa realidade atual.

\section{DO ABANDONO AFETIVO}

A Constituição da República Federativa, em seu artigo 227, prevê o dever da família, da sociedade e do Estado assegurar à criança, ao adolescente e ao jovem, com absoluta prioridade, o direito à vida, à saúde, à alimentação, à 
educação, ao lazer, à profissionalização, à cultura, à dignidade, ao respeito, à liberdade e à convivência familiar e comunitária, além de colocá-los a salvo de toda forma de negligência, discriminação, exploração, violência, crueldade e opressão.

Fica claramente demonstrado, por meio do artigo 186, do Código Civil que os pais deverão responder pelo dano decorrente do abandono afetivo, que abrangerá não só a ausência do afeto, do amor, do carinho, da atenção, da presença paterna ou materna, mas também de deixar de fazer o que é sua obrigação. Além do previsto no artigo anteriormente citado, de forma expressa, temos também o artigo 229 da Constituição da República Federativa do Brasil, que prevê o dever dos pais em assistir, criar e educar os filhos menores, e não só os pais têm obrigação em cuidar dos filhos, como também o inverso, devendo os filhos ajudar e amparar os pais na velhice, carência ou enfermidade, conhecido como abandono afetivo "inverso", também expresso no artigo $3^{\circ}$ do Estatuto do Idoso (Lei 10.741/2003):

É obrigação da família, da comunidade, da sociedade e do Poder Público assegurar ao idoso, com absoluta prioridade, a efetivação do direito à vida, à saúde, à alimentação, à educação, à cultura, ao esporte, ao lazer, ao trabalho, à cidadania, à liberdade, à dignidade, ao respeito e à convivência familiar e comunitária.

Além dessas formas de abandono afetivo, é possível constatar que o mesmo ocorre nos casos de adoção, com a devolução do adotando, por aquele que o adotou, sem nem ao menos justificativa plausível, como é considerado no caso em que o adotando não se adapta ao ambiente familiar no qual é recebido. Observe-se bem, o adotando somente pode ser "devolvido" se este não se adaptar ao ambiente familiar. Não há que se falar quanto à família não se adaptar ao adotando. Afinal, no momento em que duas pessoas, em plena capacidade civil, 
decidem por ter o anseio de adotar, entrando inclusive, numa fila de espera para que seu desejo se torne realidade, estes já sabem os possíveis "riscos" que a adoção traz consigo. Não tendo, portanto, estes o direito de se reportar na decisão tomada, no caso de esse não ser o desejo do adotando.

Sendo que, para que, ocorra enfim, a devolução do adotando, há um prazo previsto legalmente, no artigo 46 do Estatuto da Criança e do Adolescente, definido como "estágio de convivência" que se dá no decorrer de 90 (noventa) dias, sendo observadas a idade do adotando, bem como as peculiaridades em acordo com cada caso e sua realidade. Sendo sempre ressaltado que, apenas o estágio de convivência, por si só, não serve de justificativa legítima para a conduta que, voluntária ou negligente, acarrete prejuízo, seja ele emocional, psicológico ou material à criança ou adolescente entregue para fins de adoção, vindo a ferir os princípios fundamentais do adotando.

Quanto ao abandono afetivo cometido pelos pais para com seus filhos, o Estatuto da Criança e do Adolescente prevê em seu artigo $5^{\circ}$, que o agente que de forma comissiva ou omissiva, prive de alguma forma a criança aos seus direitos fundamentais,

será punido na forma da Lei. O que demonstra que, de fato, aquele que comete o abandono afetivo deve ser punido por tal omissão ao seu dever. Neste sentido, o judiciário vem inovando, podendo já ser observado, jurisprudência que visa a indenização por dano moral, para realizar tal punição. A punição é realizada através da obrigatoriedade em indenizar de forma pecuniária, ao filho que sofre com o abandono afetivo, vindo a adquirir por cunho deste, consequências psíquicas, mediante a ausência propositada da paternidade.

A indenização moral neste caso, é empregada, não como benfeitoria para o filho que sofre as consequências do abandono, mas sim, para que de alguma forma, o pai ou a mãe, que comete o abandono, venha a sentir o prejuízo causado 
ao filho, o qual ainda assim, não se compara ao sofrido pelo filho, visto que, aquele que sofre pelo abandono, jamais, haverá qualquer valor que seja capaz de demonstrar, ou cobrir o seu sofrimento.

Conforme Rodrigo da Cunha:

O Direito de Família somente estará em consonância com a dignidade da pessoa humana, se determinadas relações familiares, como o vínculo entre pais e filhos, não forem permeados de cuidado e de responsabilidade, independentemente da relação entre os pais, se forem casados, se o filho nascer de uma relação extraconjugal, ou mesmo se não houver conjugalidade entre os pais, se ele foi planejado ou não. (...) Em outras palavras, afronta o princípio da dignidade humana o pai ou a mãe que abandona seu filho, isto é, deixa voluntariamente de conviver com ele". (PEREIRA, 2015, p. 406).

Configura-se ato ilícito, o abandono afetivo, mediante a infringência do disposto no artigo 227 e 229, da Constituição da República Federativa do Brasil, conforme exposto acima, a partir do momento em que por ação ou omissão voluntária, negligência ou imprudência, violar direito e causar dano a outrem, ainda que exclusivamente moral, comete ato ilícito, em acordo com o artigo 186, do Código Civil. Indubitavelmente, aquele que comete ato ilícito deve ser alvo de suas consequências, bem como responsabilizado por seus atos.

O afeto entre pais e filhos, é um dos elementos norteadores para que a criança tenha uma boa estrutura psíquica para enfrentar as futuras adversidades com maior desenvoltura, bem como para que o idoso, no caso pai ou mãe do que comete o abandono, possa ter uma expectativa de final de vida física digno.

A afetividade na relação pai-filho, assim como em todos os outros tipos de relacionamento, é um importante fator, vez que a afetividade molda a questão da compreensão, do querer o outro bem e lutar por isso.

Considera-se a afetividade (afeto+idade), a qualidade psíquica de um conjunto de fenômenos, que se manifesta sob a forma de emoções, sentimentos 
como alegria ou tristeza, trazendo a impressão de prazer ou de dor, dentre tantos outros.

Essas emoções devem ser cuidadas com excelência, afinal de contas, elas serão o melhor suporte para que a vida da criança seja equilibrada no futuro, bem como para que esta saiba distinguir as formas de agir, de se portar diante de determinadas situações, ou até mesmo de tomar decisões em sua vida, ou para que o final de vida dos pais, sejam pautados em tranquilidade e dignidade.

Dessa forma, o afeto pode ser considerado um dos fundamentos mais importantes para um crescimento saudável da criança. Afinal, os seus efeitos perdurarão por toda a vida da criança, sendo que a sua falta pode ser um incentivo ao desenvolvimento de comportamentos antissociais, além de traumas, que poderão tornar a convivência com outras pessoas, algo insustentável.

Conforme o enunciado $8^{\circ}$ do Instituto Brasileiro de Direito de Família: “O abandono afetivo pode gerar direito à reparação pelo dano causado". Com relação a este enunciado, vêm surgindo decisões, que deferem o pedido de indenização por dano moral, ensejada pelo abandono afetivo. O doutrinador e Presidente do Instituto Brasileiro do Direito de Família, Rodrigo da Cunha Pereira, atuou na primeira ação judicial em que foi reconhecida a indenização extrapatrimonial por abandono afetivo. Nesta, o Tribunal de Alçada de Minas Gerais condenou um pai ao pagamento de duzentos salários-mínimos referente aos danos morais causados ao filho por não ter convivido com ele. (Apelação Cível n. 408.550-5 da Comarca de Belo Horizonte - Sétima Câmara Cível.)

No entanto, o Superior Tribunal de Justiça reformou a decisão do Tribunal de Minas Gerais, decidindo não se tratar de ato ilícito, devido a não ser o pai obrigado a amar o filho. Sendo assim, o abandono afetivo incapaz de gerar reparação pecuniária. (STJ, Recurso Especial 757.411/MG - 29 de novembro de 2005) 
Porém, essa decisão não teve força para encerrar o debate sobre o assunto; afinal, conforme exposto pelo artigo 1.634, do Código Civil, fica claramente demonstrado o dever dos pais, perante o poder familiar, de criar, educar e guardar os filhos. Além de estar expressamente demonstrado este dever também na Constituição da República Federativa do Brasil. Sendo que, qualquer destes deveres ao ser violado, viola um direito, trazendo a criança, ao adolescente ou ao jovem, o direito de ser indenizado por tal violação. Sendo a obrigação de indenizar prevista no artigo $5^{\circ}$, da Constituição da República Federativa do Brasil, nos incisos $\mathrm{V}$ e X.

Na mesma linha de intelecção está a Professora Giselda Maria Fernandes Novaes Hironaka (2002, p. 98-99)

\begin{abstract}
A responsabilidade dos pais consiste principalmente em dar oportunidade ao desenvolvimento dos filhos, consiste principalmente em ajudá-los na construção da própria liberdade. Trata-se de uma inversão total, portanto, da ideia antiga e maximamente patriarcal de pátrio poder. Aqui, a compreensão baseada no conhecimento racional da natureza dos integrantes de uma família quer dizer que não há mais fundamento na prática da coisificação familiar (...). Paralelamente, significa dar a devida atenção às necessidades manifestas pelos filhos em termos, justamente, de afeto e proteção. Poder-se-ia dizer, assim, que uma vida familiar na qual os laços afetivos são atados por sentimentos positivos, de alegria e amor, recíprocos em vez de tristeza ou ódio recíprocos, é uma vida coletiva em que se estabelece não só a autoridade parental e a orientação filial, como especialmente a liberdade paterno-filial.
\end{abstract}

A evolução quanto ao assunto não parou com a decisão prolatada pelo Superior Tribunal de Justiça no ano de 2005, tanto é que no ano de 2012, surgiu uma nova decisão quanto ao tema, no qual foi relatora a Ministra Nancy Andrighi, que ficou muito conhecida devido a exposição da seguinte frase: "amar é faculdade, cuidar é dever", tendo esta decisão resultado positivo quanto à busca pela reparação do dano moral causado em decorrência do abandono afetivo. Seguindo a ementa de tal decisão: 
Civil e Processual Civil. Família. Abandono afetivo. Compensação por dano moral. Possibilidade. 1. Inexistem restrições legais à aplicação das regras concernentes à responsabilidade civil e o consequente dever de indenizar/compensar no Direito de Família. 2. O cuidado como valor jurídico objetivo está incorporado no ordenamento jurídico brasileiro não com essa expressão, mas com locuções e termos que manifestam suas diversas desinências, como se observa do art. 227 da CF/1988. 3. Comprovar que a imposição legal de cuidar da prole foi descumprida implica em se reconhecer a ocorrência de ilicitude civil, sob a forma de omissão. Isso porque o non facere, que atinge um bem juridicamente tutelado, leia-se, o necessário dever de criação, educação e companhia - de cuidado -, importa em vulneração da imposição legal, exsurgindo, daí, a possibilidade de se pleitear compensação por danos morais por abandono psicológico. 4. Apesar das inúmeras hipóteses que minimizam a possibilidade de pleno cuidado de um dos genitores em relação à sua prole, existe um núcleo mínimo de cuidados parentais que, para além do mero cumprimento da lei, garantam aos filhos, ao menos quanto à afetividade, condições para uma adequada formação psicológica e inserção social. 5. A caracterização do abandono afetivo, a existência de excludentes ou, ainda, fatores atenuantes - por demandarem revolvimento de matéria fática - não podem ser objeto de reavaliação na estreita via do recurso especial. 6. A alteração do valor fixado a título de compensação por danos morais é possível, em recurso especial, nas hipóteses em que a quantia estipulada pelo Tribunal de origem revela-se irrisória ou exagerada. 7. Recurso especial parcialmente provido. (STJ, REsp 1.159.242/SP, Terceira Turma, Rel. Min. Nancy Andrighi, j. 24/04/2012, DJe,10/05/2012).

Tal decisão demonstra a total possibilidade de aplicação do conceito de dano moral nas relações familiares, visto que, os pais têm o dever de dar auxílio psicológico aos filhos, e no não fazer ou não cumprir com essa obrigação, resta demonstrado o dano moral.

Claro que, conforme qualquer outro pedido por reparação de danos, sejam patrimoniais ou extrapatrimoniais, com o abandono afetivo não é diferente. Deve ser comprovado o dano causado. O que deve ser feito através de análise psicanalista, e devidamente demonstrado o motivo causador do distúrbio, ou doença psicológica que tenha sido aderida pelo filho ou pelo pai, ou seja, pelo sujeito passivo ao abandono. 


\section{AS CONSEQUENNCIAS DO ABANDONO AFETIVO PATERNO NA VIDA DA CRIANÇA/ADOLESCENTE}

No dia 11 de agosto de 2019, data comemorativa conhecida como "Dia dos Pais", foi lançado um documentário, chamado "Todos nós 5 milhões", na plataforma digital "Youtube", que demonstra justamente o abandono afetivo e suas consequências, para aqueles que convivem ou conviveram com tal sofrimento. O nome do documentário teve origem em dados de uma pesquisa do Conselho Nacional de Justiça, que demonstrou que no Brasil, existem mais de cinco milhões de crianças que são matriculadas no ensino regular e não possuem o nome do pai, sequer no registro de nascimento. No documentário, é relatado inclusive pelas mães, a dificuldade vivida, desde a gestação ao nascimento, bem como na criação dos filhos sem a presença do pai.

Nesse documentário, inclusive, as mães dizem que, para alguns pais, a paternidade parece ser vista como uma opção, ou seja, como se tivessem os pais, de forma putativa, a possibilidade de se escolher, entre ser ou não ser pai, tratando-se ainda, a concepção de um filho, com um velho jargão que diz que "filho é da mãe". As mães relatam ainda o fato de que a visão do mundo, é horrenda para aquelas que entram com pedido de alimentos na justiça, como se esta não fosse uma das obrigações inerentes dos pais ao se ter filhos. É gravado também o depoimento de um pai que trata a paternidade como "frustração de sua liberdade", além de filhos, que hoje são maiores de idade, e relatam a falta da presença dos pais, ainda que possuam "supermães".

Uma realidade fática, assim como demonstrado no documentário, pode ser observada no dia a dia. A cada dia que se passa, ainda que hoje já seja possível a responsabilização dos pais, alguns pais se tornam mais distantes dos filhos. 
No decorrer dos anos, as mulheres têm se tornado mais independentes, e com isso, os pais vem se eximindo da responsabilidade perante os filhos. No entanto, é perceptível que, por maior e mais constante que seja a presença da mãe na vida de um filho, ou até mesmo dos avós, dentre outras pessoas que o amam, a falta que o afeto paterno faz na vida desta criança, jamais será suprida por outro que não seja seu pai.

A presença do afeto advindo dos pais é essencial ao desenvolvimento da criança. Grande parte dos casos de abandono afetivo paterno ocorre após a separação conjugal dos pais, visto que esta traz diversas mudanças no círculo familiar, tanto na vida do homem, quanto na vida da mulher, mas principalmente na vida dos filhos.

Ainda que haja previsão legal expressa de que o divórcio em nada altera a obrigação dos pais com os filhos, conforme disposto no artigo 1.579, do Código Civil, é possível observar que a mudança é real e gera efeitos inevitáveis na vida dos envolvidos na relação.

Na maioria dos casos, após a separação conjugal, a guarda dos filhos, fica para a mãe, são raros os casos em que ocorre o inverso. E com isto, os pais acabam se distanciando, por vias de fato de ter que lidar com a mãe nas visitas aos filhos. Ainda que muitos mantenham o desejo de conviver, educar e se manter por perto, acabam evitando o contato com o filho, por psicologicamente, estarem barrados pela presença da ex-cônjuge.

Aí é quando surge a maior preocupação em relação às crianças, afinal, os filhos ficam em meio à guerra, ainda que psicológica, que ocorre entre seus pais. Sendo levados, muitas das vezes, de um lado para o outro, sem nem sequer entender o que de fato está acontecendo.

Com a separação conjugal, muitos pais, acabam se desvinculando não só da ex- cônjuge, como também dos filhos, que em grande parte perdem qualquer 
possível forma de contato e convivência com o pai, se tornando a cada dia mais raro o afeto entre estes, sendo deixado de lado o princípio do melhor interesse da criança, que existe com base em Lei.

Segundo a psicóloga Rosângela Martins (2019):

É essencial de que o casal não envolva os filhos em seus desentendimentos, mantendo-os fora da discussão. Estudos realizados mostram que distúrbios emocionais que ocorrem com os filhos de pais separados, não se devem necessariamente a separação, mas a outros fatores envolvidos com a separação, tais como pais que apresentam distúrbios de comportamento, que brigam muito e que envolvem os filhos nestas brigas. Quando o processo de separação é bem conduzido, a criança não é seriamente afetada e pode ficar mais tranquila à medida que observa que os pais tomaram uma decisão acertada e se sentem melhor assim; com a separação.

Fato é que, conforme citado acima, é comum a distância entre pais e filhos após a separação conjugal. No entanto, ainda que haja o rompimento dos elos matrimoniais, o vínculo de parentesco construído com os filhos jamais deve se romper, bem como não se deve dar espaço para a alienação parental.

Com o passar dos anos, a guarda tem sofrido uma brusca alteração quanto as definições realizadas pelo Judiciário, vez que tem sido muito comum a homologação da guarda compartilhada entre a mãe e o pai, mas ainda não tem sido muito adaptável à realidade, mediante a acomodação dos pais em já se definir antes mesmo de chegar ao Judiciário que a responsável pela guarda dos filhos seja a mãe, sendo que o próprio Código Civil, traz em seu artigo 1.566, inciso IV, que se trata de obrigação de ambos os cônjuges sustentar, guardar e educar os filhos.

Em detrimento do abandono afetivo, tem surgido algumas causas, já com decisão pelo Judiciário a respeito da indenização pelo dano moral decorrente do abandono afetivo, porém, muitos questionam a relação entre tal indenização e o 
afeto de fato, bem como questionam a relação entre o afeto e o amor, que são distintos.

De acordo com Tartuce (2019):

[...] o afeto não se confunde necessariamente com o amor. Afeto quer dizer interação ou ligação entre pessoas, podendo ter carga positiva ou negativa. $\mathrm{O}$ afeto positivo, por excelência, é o amor; o negativo é o ódio. Obviamente, ambas as cargas estão presentes nas relações familiares.

Ou seja, o afeto positivo vindo dos pais é extremamente relevante para o desenvolvimento dos filhos. E deveria ser dado sem qualquer tipo de cobrança, afinal de contas o amor não possui valor econômico, e não tem como, de forma alguma, ser forçado. É um sentimento natural, que certamente fica cada vez mais restrito se não houver convivência entre os envolvidos.

Podemos nos dar conta disso ao imaginar: bem, um filho, desde o ventre de sua mãe, já possui reações voluntárias, ao perceber a presença do pai por perto, ou ao ouvir a voz de sua mãe. Mas se analisarmos a fundo, o pai ao não conviver com este crescimento do bebê, não terá em si, o despertar do amor desde tal fase.

Assim como uma criança que não tem convivência com uma pessoa, e com isso, não está acostumado com aquela companhia por perto, se assustará, ou no mínimo recuará de forma natural, e não é diferente com o pai que é ausente em sua vida, no seu dia a dia.

O amor é o principal sentimento a ser desenvolvido na vida de uma pessoa, seja em qualquer tipo de relação. É deste que advém a harmonia, a compaixão, a gratidão, e todos os outros sentimentos bons, que proporcionam prazer ao viver em comunhão. Motivo pelo qual, grande parte das crianças ou adolescentes que sofrem com o abandono afetivo dos pais, desempenham grande 
aptidão a serem mais agressivas, ou menos conformistas, adaptáveis, com as situações as quais a vida as impõe.

O afeto, o cuidado e o conforto que ambos os pais geram para a criança, ou adolescente, são essenciais em sua formação psíquica, que ocorre nos primeiros anos de vida. E a ausência destes, pode gerar consequências duradouras na vida deste ser. Como por exemplo, distúrbios psicológicos que impossibilitem uma boa convivência em sociedade.

Há algum tempo, psicanalistas vêm desenvolvendo pesquisas, com parâmetro na base que advém do convívio e afeto entre pais e filhos, para que fosse analisado cientificamente as consequências trazidas pelo abandono afetivo ou separação de tais partes.

Nos anos entre 1940 e 1944, John Bowlby (apud DALBEM; DELL'AGLIO, 2006), realizou estudos nesse sentido, formulando a Teoria do Apego, que foi desenvolvida com base nas observações sobre o cuidado inadequado na primeira infância e o desconforto e a ansiedade de crianças pequenas em relação à separação dos cuidadores. Tal teoria teve embasamento na adaptação desta criança ao mundo real. Não só nesta linha de pensamento, outro conceito da Teoria do Apego é o comportamento do apego, que é o que leva uma pessoa a alcançar ou manter proximidade com outro, sendo este um aspecto fundamental para lidar com o mundo externo. Segundo Bowlby (apud DALBEM; DELL'AGLIO, 2006), essa função corresponde a necessidade natural de proteção e segurança.

Um outro autor, B. Golse (apud DALBEM; DELL'AGLIO, 2006) salienta que tal comportamento de apego é algo instintivo, ou seja, é natural do ser humano, e é herdado ao longo da vida, não sendo desta forma, algo genético. No entanto, o potencial ou tipo de código genético, que permite à espécie desenvolver melhores resultados adaptativos, é herdado. Enfim, assim como o 
mundo externo gerará efeitos na vida e nas ações do indivíduo, o cuidado e afeto recebido dos pais fará toda a diferença nestes resultados.

Resultados que podem ser positivos ou negativos, afinal de contas, toda ação gera uma reação, que será o efeito direto do que foi recebido. Só que, o que o ser já tem dentro de si, é que definirá a sua reação a cada fato, a cada contato direto com o mundo e outros seres, que por si só, também possuem ações e reações. Conforme a distinção feita por Bowlby, existem dois tipos de fatores que interferem na ativação comportamental do apego: aqueles que mantém relação com condições físicas e temperamentais da criança, e os relacionados às condições do ambiente, que somados influenciaram no desenvolvimento cognitivo e nas respostas afetivas, envolvidas as figuras com as quais a criança se baseia, bem como a experiência vivida por ela.

Ora, se a criança vive em um ambiente saudável, no qual faz boas memórias e tem motivação para desempenhar seus instintos, de forma natural e satisfatória, essa criança terá acesso ao mundo, de forma menos pesada e mais benéfica tanto para si, quanto aos que estão em sua volta. Já se essa criança cresce num ambiente onde, só existem brigas, confusões, desafeto, ausência de estímulo e motivação, indubitavelmente seus impulsos serão reflexos do que ela viveu em seus primeiros anos de vida. O que fará muito possivelmente dessa criança, um ser sem esperança, sem motivação para se tornar alguém melhor e desenvolver o que há de positivo dentro de si. Não há como refletir em um espelho algo bom, se o que está do outro lado não é semelhante a isto.

Mediante pesquisas, Mary Ainsworth (apud DALBEM; DELL'AGLIO, 2006), criou um sistema de avaliação do relacionamento mãe-bebê, podendo ser observado a interação destes, de forma naturalística, sendo identificados dois tipos de apego: os seguros e os inseguros. Os seguros tinham em seus cuidadores, uma base para exploração confiante do ambiente, enquanto os inseguros 
apresentavam baixa exploração do ambiente e pouca ou intensa interação com suas mães.

Mary Ainsworth, em 1978 desenvolveu o método experimental “Situação Estranha", que foi publicado no artigo "Patterns of attachment", no qual classificou o apego em quatro padrões: padrão seguro, padrão ambivalente ou resistente, padrão evitativo e padrão desorganizado ou desorientado.

No padrão seguro, foi observado que o relacionamento cuidador-criança, desenvolvido em uma base segura, fez com que a criança explorasse o ambiente de forma entusiasmada e motivada e, ainda, nos momentos de estresse, tais crianças demonstraram confiança em obter cuidado, além de, quando separadas de seus cuidadores, se sentirem incomodadas, mas não se abaterem de forma exagerada.

Já o padrão ambivalente ou resistente, foi caracterizado por crianças que, na presença dos cuidadores apresentaram comportamento imaturo para a idade e com pouco interesse em explorar o ambiente, resultando com que os cuidadores ficassem preocupados. Longe dos cuidadores, estas crianças se mostravam incomodadas, de forma a nem sequer se aproximar de pessoas estranhas. E no retorno dos cuidadores para perto, essas crianças demonstravam uma certa braveza, não querendo se reaproximar facilmente a estes. O que demonstrou que, muito provavelmente, nestas relações, as crianças receberam cuidados de acordo com suas demandas em alguns momentos, enquanto em outros não obtiveram resposta de apoio, o que pode ter gerado uma certa falta de confiança, em relação aos cuidados, à disponibilidade e à responsividade.

No padrão evitativo, as crianças brincam de forma tranquila, interagindo pouco com seus cuidadores, sendo inibidos com estranhos, e engajadas em brincadeiras propostas, ainda que com pessoas desconhecidas, sem os cuidadores por perto. Ainda com a volta de seus cuidadores para perto, as 
crianças continuam seguras, sem necessitar do conforto dos cuidadores. A maior característica evidenciada por M. Ainsworth, ao observar as crianças deste grupo, é que muito provavelmente seriam crianças que se envolvem com momentos estressantes, o que as torna menos propensa a procurarem pelo conforto dos cuidadores, devido a, em algum momento, terem sido rejeitadas, quando revelaram suas necessidades.

Finalmente, no grupo desorientado ou desorganizado, encontraram-se crianças que, em momento algum demonstraram apego aos cuidadores. Muito pelo contrário, quando os cuidadores estiveram por perto, essas crianças tiveram, de forma clara, expressões negativas em seus rostos, com demonstração de impulsividade, perturbação e até mesmo medo. O que normalmente ocorre com crianças que sofrem abuso, sendo o abusador externo e ameaçador a criança, ou até mesmo quando o abusador se trata do próprio cuidador.

Mediante os estudos, pode-se constatar que, a demonstração de afeto, principalmente sendo o sujeito passivo, a criança, é completamente importante e essencial em seu desenvolvimento, afinal, é na primeira infância que se define o futuro, a forma como a criança irá se portar no decorrer da vida.

E é claro que em sua grande maioria, as figuras com quem a criança convive desde o nascimento, no caso os pais, é que se tornarão uma espécie de espelho, ou seja, serão tomadas como exemplo pela criança.

Não obstante das pesquisas acima, foi realizada também uma entrevista direcionada aos adolescentes, de modo a ser analisado a influência do apego na adolescência inicial, bem como na adolescência propriamente dita. Foi comprovado, através dos estudos, que, nos primeiros 04 anos da adolescência, entre os 12 e 15 anos de idade, há uma maior rejeição da participação dos pais, o que demonstra nesta etapa, em sua grande maioria, o padrão 
evitativo/desapegado, pois é o período em que o adolescente se priva da convivência extrema com os pais, para formar sua própria identidade.

Crittenden (apud DALBEM; DELL'AGLIO, 2006) ressalta que na adolescência, os indivíduos tendem a alterar as figuras de apego, para que, se habilitem para relacionamentos fora do círculo familiar. Ao lidar com o mundo, onde serão construídas relações com seres estranhos ao círculo familiar, o adolescente se vê diante da necessidade de realizar modificações no seu entendimento, no entendimento formado durante a sua infância, modificações estas necessárias perante os novos desafios e novas convivências, momento este no qual, a interferência constante dos pais, ou das figuras de seus cuidadores, pode ser contingente das ansiedades provenientes destas mudanças. Instante em que se faz necessário deixar o apego de lado, para que se torne possível o desenvolvimento da autonomia deste adolescente.

Com o aproveitamento dos estudos apontados anteriormente, bem como comprovação do constatado, Cornelis George Boeree, N. Kaplan e Mary Main (apud DALBEM; DELL'AGLIO, 2006), criaram a “Entrevista do Apego do Adulto", na qual, através de questões estruturadas minuciosamente, é explorada a relação do indivíduo com seus pais no decorrer da infância, bem como os efeitos dessa experiência, em sua vida atualmente.

Através da entrevista, foram formuladas, para os destinatários, quatro padrões, de prospecção, aos criados anteriormente, definindo os padrões das crianças. Quais sejam, os padrões: seguro/autônomo, preocupado/ansioso, evitativo/desapegado e desorganizado/desorientado.

Nessa etapa, a categoria segura/autônoma, que busca um paralelo com as expressões das crianças do grupo seguro, é evidenciado que, os adultos entrevistados, relatam de forma segura, tranquila, e relembram das boas 
experiências vividas na infância, com caráter positivo, demonstrando ainda, valorizar os relacionamentos de apego.

Já no padrão evitativo/desapegado, os adultos têm dificuldade em lembrar da infância, sendo incapazes de se recordar de memórias específicas em apoio do argumento geral, e demonstram a idealização ou desvalorização dos primeiros relacionamentos de apego.

No padrão preocupado/ansioso, as experiências são relatadas de forma confusa ou conflitante, não sendo os adultos entrevistados hábeis para apresentar um roteiro coerente sobre suas experiências, sendo demonstrado raiva ou medo em relação as figuras de apego, queixando-se ainda, em algumas vezes de desrespeitos da infância.

O padrão do adulto considerado como desorientado/ desorganizado apresenta sinais graves de desorientação, demonstrando isso claramente ao serem entrevistados quanto a momentos traumáticos da infância.

Sendo de fato, comparadas as pesquisas realizadas entre crianças, adolescentes e adultos, é possível ver a presença do apego e do afeto em cada uma delas, caracterizado por diferentes fases e momentos da vida, interligados entre cada uma destas. Afinal, enquanto criança, o apego lhe serve como uma certa base, para desenvolver segurança, confiança em si mesmo, e já dar início à convivência com o mundo exterior. No momento em que a criança dá o próximo passo em direção a adolescência, todo esse apego passa a ser lapidado, afinal, é o momento em que se cria a própria personalidade, passando a tomar algumas decisões, e ao chegar na fase adulta, se tem toda a experiência já vivida nas duas fases anteriores, que demonstrará todo o vivido, através das decisões tomadas, do modo de agir, do modo de pensar, bem como de se portar perante os desafios que a vida o colocará frente a frente, a cada dia. 
Segundo Tânia da Silva Pereira (2008, p.309), “o ser humano, precisa ser cuidado para atingir sua plenitude, para que possa superar obstáculos e dificuldades da vida humana". Alertando a autora para o fato de que o "não cuidado" pode vir a desenvolver no indivíduo, sentimentos estarrecedores como: impotência, perda, desvalorização como pessoa e vulnerabilidade, além de "tornar-se uma cicatriz que, embora possa ser esquecida, permanece latente na memória".

A falta de afeto, o não cuidado, o deixar de amar, pode repercutir em diversas fases da vida, tornando seres que disseminam o ódio, pela falta de amor que receberam, bem como ansiando pelo mal.

Como o ditado popular "o ser só dá aquilo que recebe", é a realidade. O ser humano não tem como ensinar, sem antes aprender ou conhecer sobre o assunto. Como dará amor, recebendo o desamor?! Esse fato se comprova mediante os pequenos distúrbios, como as demonstrações de ódio, até doenças psicológicas como a depressão, por exemplo.

Diante das demonstrações acima, é possível se chegar ao provável resultado, de um ser, na evolução da vida, sendo ausente o pai, carente do amor e atenção que deveria ter recebido em cada fase, como o apoio, a segurança, o porto seguro que os pais tendem a ser para os filhos, é de grande possibilidade de que, esse ser, seja uma pessoa traumática, insegura, relativamente instável, bem como propensa a desenvolver doenças que levará consigo por toda a vida, podendo ainda ser espelho de todo o vivido por si para suas futuras gerações, sem que nem sequer se dê conta do motivo causador de tanto distúrbio e frustrações que a falta do afeto, do amor, do apego, podem causar de forma naturalística e horrenda.

\section{Considerações Finais}


Conforme demonstrado anteriormente, e diante de todo o exposto, o afeto tem uma posição extremamente importante, durante toda a vida do ser, contudo, é indispensável na fase da primeira infância, momento na qual a personalidade passa a ser constituída e cada detalhe faz total diferença no desenvolvimento psíquico do ser.

Todas as experiências que a criança viver, bem como todas as influências, farão parte do que ela se tornará no futuro, afinal, conforme demonstrado nas pesquisas dos psicanalistas citadas acima, os padrões seguem por toda a vida, dificilmente uma criança que têm uma infância insegura, ou baseada no medo, irá ser um adulto seguro com desenvoltura o bastante para saber lidar com as imposições e obstáculos que a vida lhe trará.

Conforme a frase pela qual a Ministra Nancy Andrighi, ficou bastante conhecida, "amar é faculdade, cuidar é dever", pode-se observar o claro dever dos pais em cuidar, em ser base, em ser alicerce para os filhos, não há, nem jamais haverá espelho maior para uma criança, do que seus pais, que além de material genético, irão ter grande influência em quem os filhos se tornarão futuramente.

E conforme todo delito causado, o sujeito ativo, no caso o agente garantidor, o pai, ou que seja a mãe, deve ser punido pela omissão ao seu dever, além de privar os filhos de direitos que são seus, por garantia.

Claro é que seria bem mais satisfatório que todos os pais tivessem prazer em conviver com seus filhos, afinal, a lógica seria olhar para os filhos com orgulho, pois queiram os pais ou não, os filhos são uma espécie de continuação de seu gene no mundo.

Indubitavelmente o abandono afetivo traz sérias consequências a vida do filho, que sofre com esta situação, e possivelmente viverá com esse sofrimento 
por toda a vida, tendo como marca, que jamais será apagada, além de gerar efeitos nas relações deste filho com o mundo externo.

Nas palavras do Deputado Carlos Bezerra, em seu projeto de Lei 4.294/08: “a espera por alguém que nunca telefona, sequer nas datas mais importantes-, o sentimento da rejeição e a revolta causada pela indiferença alheia provocam prejuízos profundos em sua personalidade".

A mente do ser humano é capaz de guardar desde aparentes pequenos fatos, até os mais intensos e extensos, no entanto, a capacidade para se recordar do que causa dor, tem maior propensão de ser lembrada. Com isso, aquele que passa pelo abandono afetivo paterno terá grande possibilidade em jamais esquecer aquela apresentação no dia dos pais na escola, onde o pai nunca apareceu; aquele abraço que tão somente ele poderia suprir; aquela visita prometida e não cumprida, ou simplesmente aquele sentimento de orgulho, daquele que deveria ter a figura de super-herói; afinal, é assim que grande parte das crianças fantasiam os pais.

Além disso, é válido ressaltar a consideração de Rolf Madaleno, "o afeto é mola propulsora dos laços familiares e das relações interpessoais movidas pelo sentimento e pelo amor, para ao fim e ao cabo dar sentido e dignidade à existência humana".

Por fim, num mundo o qual por natureza, de forma espontânea, já se tem lugar tanta disseminação do ódio, por meio de palavras soltas, que dão significado à dor, ao sofrimento, a indignação, gerando o repúdio, não deveria dar-se azo ao desamor dentro do lar, onde de forma instantânea, já se cria no ser humano o entendimento de que o lar seja o lugar de paz e segurança, o lugar que serve para se desabafar e ter de volta a paz, ou seja, os pais deveriam criar seus filhos com amor, cuidado, zelo, e acolhimento, dando, dessa forma, o apoio necessário para que os seus filhos não sejam os próximos a ter uma parcela de 
culpa para que o mundo se torne insustentável para se viver em paz. Lembrandose que a família é a entidade na qual o ser humano encontra alicerce, tem seus primeiros aprendizados, ou seja, a base que carregará consigo no decorrer de toda a vida.

\section{Referências}

BRASIL. Código civil - Lei n 10.406, de 10 de janeiro de 2002, [2018].

Disponível em: http://www.planalto.gov.br/ccivil 03/LEIS/2002/L10406.htm.

Acesso em: 01 out. 2019.

BRASIL. Código penal - Decreto-Lei n 2.848, de 07 de dezembro de 1940, [1991]. Disponível em: http://www.planalto.gov.br/ccivil 03/decretolei/del2848compilado.htm. Acesso em: 01 out. 2019.

BRASIL. Constituição da República Federativa do Brasil de 1988. Brasília, DF; Presidência da República, [2016]. Disponível em:

http://www.planalto.gov.br/ccivil 03/constituicao/constituicaocompilado.htm>. Acesso em: 01 out. 2019.

BRASIL. Estatuto da Criança e do Adolescente - Lei n 8.069, de 13 de julho de 1990, [2019]. Disponível em:

http://www.planalto.gov.br/ccivil 03/leis/18069.htm. Acesso em: 01 out. 2019.

BRASIL. Estatuto do Idoso - Lei n ${ }^{\circ}$ 10.741, de 01 de outubro de 2003, [2007].

Disponível em: http://www.planato.gov.br/ccivil 03/leis/2003/110.741.htm.

Acesso em: 01 out. 2019.

BRASIL. Instituto Brasileiro de Direito de Família. Criado em 25 de outubro de 1997, sendo uma entidade técnico-científica, sem fins lucrativos, com o objetivo de desenvolver e divulgar o conhecimento sobre o Direito de Família. Disponível em: http//www.ibdfam.org.br/.Acesso em: 01 out. 2019. 
BRASIL. Lei da Primeira Infância - Lei n 13.257, de 08 de março de 2016.

Disponível em: http://www.planalto.gov.br/ccivil 03/ Ato2015-

2018/2016/Lei/L13257.htm. Acesso em: 01 out. 2019.

BRASIL.Superior Tribunal de Justiça. REsp 1.159.242/SP. Terceira Turma. Rel. Min. Nancy Andrighi. J. 24/04/2012. Dje.10/05/2012.

DALBEM, Juliana Xavier; DELL'AGLIO, Débora Dalbosco. Teoria do apego: bases conceituais e desenvolvimento dos modelos internos de funcionamento. Artigo aprovado em 17 de junho de 2006. Disponível em: $\leq$ http://pepsic.bvsalud.org/scielo.php? script=sci_arttex\&pid=S180952672005000100003>. Acesso em: 01 out. 2019.

GONÇALVES, Carlos Roberto. Direito civil brasileiro: direito de família. 9. ed. São Paulo: Saraiva, 2012. v. 6.

HIRONAKA, Giselda Maria Fernandes Novaes. Os contornos jurídicos da responsabilidade afetiva nas relações entre pais e filhos: além da obrigação legal de caráter material. Novos Estudos Jurídicos, ano VII, n. 14, p. 98-99, abril/2002.

MADALENO, Rolf. Curso de direito de família. 4. ed. São Paulo: Forense. p.95.

MARTINS, Rosângela. Os filhos e a separação conjugal. Disponível em: $\leq$ http://www.rosangelapsicologa.com/site pagina.php?pg=textos\&texto $=24>$. Acesso em: 09 out. 2019.

PEREIRA, Rodrigo da Cunha. Responsabilidade civil por abandono afetivo. In: MADALENO, Rolf; BARBOSA, Eduardo (coord.). Responsabilidade civil no direito de família. São Paulo, Atlas, 2015, p.406.

PEREIRA, Tânia da Silva. Abrigo e alternativas de acolhimento familiar. In: PEREIRA, Tânia da Silva; OLIVEIRA, Guilherme de. O cuidado como valor jurídico. Rio de Janeiro: Forense, 2008, p. 309.

TARTUCE, Flávio. O Princípio da Afetividade no Direito de Família. Disponível em: http://flaviotartuce.jusbrasil.com.br/artigos/121822540/oprincipio-da-afetividade-no-direito- de-familia>. Acesso em: 09. out. 2019. 